\title{
El silencio del ser y la interpelación del agápe: Martin Heidegger y Jean-Luc Marion
}

\author{
Santiago Andrés Duque \\ UNIVERSIDAD DE ANTIOQUIA (COLOMBIA) \\ santiagoduque7@gmail.com
}

Resumen: Este artículo busca exponer en líneas generales la crítica a la tradición metafísica y onto-teológica llevada a cabo por Martin Heidegger, y la distancia frente a la misma asumida por Jean-Luc Marion. Tal crítica y contra-crítica se sitúan en el contexto de una reflexión sobre el lenguaje, el silencio y lo sagrado, asuntos que atraviesan el pensamiento de Heidegger en su intento de escucha del ser en la poesía, así como el pensamiento de Marion, que se encuentra nutrido y sostenido por la tradición de la Teología mística cristiana. A fin de resaltar la distancia entre ambos pensadores, introducimos una discusión sobre el asunto de Dios en Heidegger a partir de la interpretación del profesor argentino Néstor Corona.

Palabras clave: Onto-teología, Ereignis, poesía, agápe, distancia, silencio, alabanza.

Abstract: This article aims to point out an overview of both the critique to metaphysical and onto-theological tradition conducted by Martin Heidegger, and the distance that Jean-Luc Marion has taken towards this critique. This critique and counter-critique are analyzed from a reflection on language, the silence and the sacred, which are issues that cross Heidegger's thought in his attempt to hear Being in poetry, as well as Marion's thought, nourished and supported by the tradition of Christian mystical theology. In order to highlight the distance between both thinkers, we introduce a discussion based on the interpretation stated by Argentinean professor Néstor Corona about Heidegger's position on the issue of God.

Keywords: Onto-theology, Ereignis, poetry, agápe, distance, silence, hymn of praise. 


\section{INTRODUCCIÓN}

Según Heidegger, la metafísica surge con la marca de origen de la onto-teología, es decir, con el olvido del ser (de aquello que hace posible todo aparecer de los entes) y con la concentración de la mirada en la presencia de los entes, lo que conduce, a su vez, a la fundamentación óntica a partir de un ente superior: el Dios de la metafísica -que es, de este modo, confundido con el ser-. Heidegger lleva a cabo una particular interpretación de la historia de la metafísica en cuanto que acontecimiento del ser mismo, que se despliega hasta arribar a lo propio de la metafísica moderna de la subjetividad, donde el sujeto se convierte en la instancia privilegiada de configuración de sentido y se asiste al crepúsculo del Dios metafísico y moral, a la crisis de los valores supremos sustentados en la religión y la razón, al imperio de la técnica, en suma, al acontecimiento epocal del nihilismo. Todo ello acontece aunque las vidas de los hombres contemporáneos sigan su curso en pos del progreso, lo cual no alcanza a ocultar por completo el síntoma de la profunda crisis, el carácter declinante de nuestra época.

La metafísica implica una clausura dentro de los límites del pensamiento y el lenguaje dispuestos a partir de las exigencias de la razón y a partir de los entes, esto es, según los rigores de la técnica y el uso práctico y efectivo. La metafísica conlleva un encierro en el reino de lo finito -de los entes presentes-, en los límites de la razón suficiente que ordena el mundo como objeto para ser dominado y conocido, y que conduce, en definitiva, a la pérdida de la esencia del lenguaje y de lo humano. Es en este contexto donde surge la necesidad de la pregunta por la posibilidad de un pensamiento no metafísico, desde el que sea posible concebir, a su vez, otro lenguaje y otro modo de la acción humana, del habitar en la Tierra. Este lenguaje implicaría un movimiento de descentramiento del sujeto, que lo sitúe en coordenadas ya no preestablecidas por sí mismo, que lo reenvíe a lo Otro, que lo abra a lo infinito. Este lenguaje dispondría al sujeto según otros principios que los ego-lógicos, lo introduciría en un juego distinto al juego especular, en el que siempre le es devuelto su mismo rostro, y, así, abriría para él otro modo de ser en el mundo.

Heidegger acaba buscando esta posibilidad del lenguaje y del habitar en la poesía, enmarcado todo ello en su propia estructura de pensamiento, arraigada en la pregunta por el ser y planteada a partir de diversas categorías y modos de expresión. Marion entra en diálogo con el pensador 
alemán desde el horizonte abierto por su pregunta, con el fin de indagar, a su vez, de un modo propio, desde un lugar liminar entre la filosofía y la teología, por el alcance del pensamiento del ser, específicamente cuando este es medido en relación con lo que aún habría que pensar de lo divino y de Dios.

Marion pone sin ambages la pregunta por Dios en el centro de su pensamiento como un asunto de la mayor seriedad que no tiene por qué ser reducido a las fronteras de una disciplina, sino que debe ser seguido según la pauta fijada por su propio rigor, respondiendo a él con distintas modulaciones de discurso, según su exigencia, ya sea desde la filosofía o desde la teología. En el despliegue de este pensamiento que busca dejarse instruir tanto por la tradición filosófica como por la tradición teológica cristiana, Marion halla en Dionisio Areopagita un maestro excepcional, cuya marca puede constatarse, incluso cuando no es mencionado, en el centro de sus ideas sobre Dios y el ser. Así, la concepción de un lenguaje y un pensamiento no metafísicos -o, en términos de Marion, no idolátricos- encuentra en Dionisio el Místico su raíz y fundamento.

\section{HEIDEGGER: EL SILENCIO CIRCULAR}

Para Heidegger ${ }^{1}$, el lenguaje entraña el peligro de la pérdida de la esencia del hombre cuando se oculta su esencia y cae en la univocidad del lenguaje técnico o en el desgaste del lenguaje cotidiano, sobre todo en su modo más radical como habladuría. A fin de conjurar este peligro, que acecha aún más en esta época de predominio hegemónico de la técnica, Heidegger busca una relación esencial con el lenguaje en la cual no sea el hombre quien pretendidamente hable desde la ilusoria condición de sujeto, en una relación instrumental con el lenguaje, sino que sea el lenguaje mismo quien hable desde su fuente esencial a través del hombre. En Heidegger, este modo de plantear la cuestión del lenguaje, ya no con fundamento en una instancia subjetiva sino desde el lenguaje mismo, se corresponde con la crítica a la metafísica de la subjetividad moderna, que sitúa al sujeto como polo privilegiado constituyente de

M. Heidegger, Lenguaje tradicional y lenguaje técnico (Versión castellana de Manuel Jiménez Redondo [materiales del curso de doctorado El discurso filosófico de la modernidad, Universidad de Valencia, curso 1993-94]), 1962. Recuperado de http://docs.google.com/file/d/0Bx6x9vlHlfTONzEyZjExNDItMmY0Mi00Zjg3L ThmYmMtMDhkZGMxN2JmMDNj/edit?hl=en 
sentido. El movimiento que efectúa de esta manera un cambio en la pregunta por el lenguaje y por el ser deja ver el sentido de la llamada Kehre (vuelta), en la cual será de suma importancia la posibilidad de buscar el acontecimiento del habla esencial en la poesía, propiamente en aquella poesía que reflexiona sobre sí misma y sobre la palabra. En esta vía, Hölderlin será considerado por Heidegger como el poeta del poeta, precisamente porque, a su entender, este poeta se entregó en forma definitiva al destino determinado desde la esencia de la poesía, que es también, sobre todo en él, la esencia de lo sagrado.

Los ensayos que conforman De camino al habla, de Martin Heidegger, tienen como propósito común pensar la esencia del habla no a través de un discurso sobre el habla, sino mediante una disposición pensante, como la propia del diálogo, a que el habla misma indique un camino hacia su esencia. Para Heidegger, esencialmente, el lenguaje no es una posesión humana, ni un instrumento de comunicación, ni un medio de expresión, sino lo dado sobre lo que el hombre no tiene ningún dominio. En el lenguaje -"casa del ser"-, el ser habita, se mueve, fluye y se manifiesta. Por esto, el lenguaje, en cuanto que habla humana (Sprache) surgida en respuesta al Decir esencial no humano (Sage), puede propiciar en su despliegue un camino hacia el acontecer esencial del habla, es decir, hacia el ser mismo.

En uno de los textos de la obra mentada, De un diálogo acerca del ha$b l a^{2}$, Heidegger intenta pensar la hermenéutica como la escucha atenta del hombre, que así escuchando puede convertirse en mensajero, del mensaje que le es dirigido desde la esencia del habla y la esencia del aparecer. La esencia del hombre es hermenéutica, y consiste en prestar oído y voz a este mensaje que proviene desde lo esencial. El habla del hombre (Sprache), en lo que consiste propiamente su esencia, tiene lugar como este prestar oído y voz al Decir esencial (Sage), cuya proveniencia es el vacío originante, aquí nombrado como lo ilimitado, el vacío del Cielo o lo Ereignis. El japonés del diálogo afirma: "El vacío es entonces lo mismo que la Nada, es decir, este puro despliegue que intentamos pensar como lo otro en relación a todo lo que viene en presencia y a todo lo que se ausenta". Y precisa: "Para nosotros, el vacío es el nombre eminente para lo

M. Heidegger, "De un diálogo acerca del habla. Entre un japonés y un inquiridor”, en De camino al habla (Ediciones del Serbal, Barcelona 1990) 77-140. 
que usted quisiera decir con la palabra 'ser' [...]"3. Es lo "indeterminado que determina”, y que no puede ser aprehendido por el habla humana; inasible desde las categorías y los conceptos, es anterior a ellos por ser lo que los hace posibles. La esencia del habla no se dice sino que se seña, se muestra en el propio despliegue del habla y el pensamiento. "[...] [L] a esencia del habla no puede pertenecer al orden del habla" ${ }^{4}$. El señar, el enigma y el gesto, únicos que pueden indicar hacia la esencia del habla, se oponen a la estructura de la significación, en la que el signo vehicula un sentido que corresponde a una referencia. El sentido unívoco del signo no puede indicar hacia la esencia del habla.

Por su propia esencia, el hombre como hermeneuta es llamado a corresponder desde el límite de su habla a lo abierto, lo ilimitado, lo indeterminado que lo determina. Esto indeterminado es llamado $K u$, vacío del Cielo. El hombre es “[...] el que camina el límite de lo ilimitado [...]

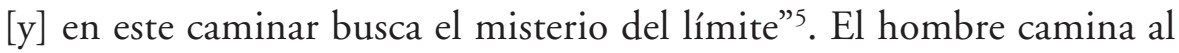
límite del vacío del Cielo, y es el habla la que lo sostiene y tiempla su esencia como indicación hacia esta ilimitación inaprehensible. Para Heidegger, aquí se enunciaría tanto una concepción del habla como del ser del hombre por fuera de la metafísica.

En De un diálogo acerca del habla se acaba por pensar la esencia del habla y del aparecer en íntima correspondencia con la esencia del arte concebida por fuera del ámbito estético, puesto que este implica una remisión a la experiencia vivida, los sentimientos y la representación de un sujeto, así como a la configuración de la obra como un objeto de la percepción (áisthesis). La esencia del arte se piensa a partir de una palabra japonesa: $I k i$, "lo que encanta con gracia", expresión esta que gravita en torno al término "gracia". La gracia, ligada al encantamiento (Entzücken), es lo advenido, no constituido por el sujeto, que arrastra (Hinzücken) hacia el silencio, más allá de todo estímulo o impresión. El encantamiento de la gracia, en cuanto que habla de la esencia, invita al silencio, indica a lo ilimitado. Por esto, en seguida, lo dicho sobre la esencia del arte es puesto en relación con la esencia del habla. El japonés afirma que la expresión japonesa para el habla es Koto ba. Ba son las ho-

\footnotetext{
M. HeidegGer, "De un diálogo...", 99.

M. Heidegger, "De un diálogo...”, 104.

M. Heidegger, “De un diálogo...”, 124.

M. Heidegger, "De un diálogo...”, 127.
} 
jas y los pétalos del ciruelo y el cerezo. Koto es, en correspondencia con la definición de $I k i$, lo que gobierna la venida del encantamiento; es la brisa del silencio, "[...] lo que de modo único, en cada instante irrepetible, viene a resplandecer con la plenitud de su gracia" . La gracia (cháris) es la inclinación benevolente que poetiza, que propicia la poiesis como surgir, desde el ocultamiento, del juego entre el ser y los entes -la Duplicidad-. La palabra japonesa Koto nombra entonces lo mismo que dice lo Ereignis: el acontecimiento apropiador como gracia y don, en el que emergen apropiados el ser a los entes y estos al ser, en mutua correspondencia. El habla es Koto ba: "pétalos procedentes de Koto": donación por la gracia de la tersura de la palabra que proviene del silencio e invita al silencio de lo ilimitado nunca apresable. Según Heidegger, la palabra que indicaría hacia lo mismo que Koto ba es die Sage: el Decir no humano que invita al habla humana (Sprache) al silencio dicente, al misterio que el mismo Decir vela, y que el habla no debe pretender hollar ${ }^{8}$. Koto ba y die Sage indicarían el círculo hermenéutico entre dos silencios: el originante de la gracia y el respondiente del hombre.

El habla que se dispone a reconducirse a su propia esencia corre el riesgo de convertirse en un habla sobre el habla, haciendo así del habla un objeto. Solo si es la esencia del habla lo que antecede, propiciando y abriendo el camino hacia ella misma, es posible conjurar este peligro. Hablar no sobre sino desde la esencia del habla implica asumir el círculo hermenéutico según el cual para emprender el camino hacia la esencia, se debe partir ya de ella. Según afirma Heidegger, solo el diálogo puede ser un decir adecuado a la esencia del habla. Además, "[u]n diálogo acerca del habla debe estar llamado por la esencia del habla" . El Decir mismo produce el verdadero diálogo donde la esencia del habla se dice a los hombres. En este diálogo habría más silencio que conversación; sería un guardar en la palabra el silencio: para mantener silencio del silencio, y, para Heidegger, solo la poesía puede callar de este modo. En el poeta, cuyo decir está antecedido por una larga escucha, “[...] el Decir encuentra voz, como el silente soplo del músico se torna música atravesando su flauta" ${ }^{10}$. A este propósito, nos dice Hugo Mujica:

\footnotetext{
M. HeidegGer, “De un diálogo...”, 129.

M. HeidegGer, "De un diálogo...", 134-135.

M. HeidegGer, “De un diálogo...”, 136.

10 H. Mujica, La palabra inicial. La mitología del poeta en la obra de Heidegger (Trotta, Madrid 1995) 97.
} 
«El Decir tiene necesidad de darse a atender a la palabra» y, en esa necesidad, realizándola, congrega al hombre -su auditor y locutor-, en el «ámbito del Decir original». En el Acontecimiento [Ereignis] cuyo Decir, diciéndose en el lenguaje humano, realiza «el misterioso juego del lenguaje»: «llevar a cabo la relación del Ser y la esencia del hombre». Esencia auscultante, apertura oyente en la que el Ser, diciéndose silentemente, hace del hombre -en la más bella de las imágenes con que Heidegger lo define- «el poema que el Ser ha comenzado» ${ }^{11}$.

Para Heidegger, atender a la relación del ser con el hombre, en la que el silencio del ser se hace audible a través de la vibración sonora del ser del hombre, convoca a la escucha de la poesía. Hölderlin es considerado por el pensador alemán como el poeta eminente, aquel que se ha dispuesto a la escucha del Decir silente (Sage) hasta ser arrastrado hacia el sagrado silencio en su propio decir poético. El siguiente verso de Como cuando en día de fiesta expresa el destino al que se ha entregado decididamente el poeta: "[...] Esperé y lo vi venir. / Y lo que vi, lo sagrado, sea ahora mi palabra"12. En Hölderlin y la esencia de la poesía ${ }^{13}$, Heidegger se refiere a Hölderlin como el poeta del poeta porque permite aproximarnos a la esencia esencial de la poesía, esto es, al despliegue del lenguaje desde sí mismo que acontece en la poesía y que, en tal despliegue, nos conduce a lo más propio y originario del lenguaje, lo cual, en Hölderlin, llevará a pensar asimismo la esencia de lo sagrado.

Hölderlin y la esencia de la poesía se desarrolla a partir de cinco lemas, que corresponden a cinco versos entresacados de algunos de los poemas de Hölderlin. Nos aproximaremos solo a dos de ellos, a fin de resaltar ciertos aspectos que nos interesan especialmente. El segundo lema abordado por Heidegger es el siguiente: "Para eso se le ha dado al hombre el más peligroso de los bienes, el lenguaje [...] para que dé fe de lo que es [...]"14. Según la interpretación de Heidegger, en el lenguaje el hombre da testimonio de lo que es, y es en el testimonio de su propia existencia. El hombre es testimonio del ser mismo. Este testimonio indica justamente la pertenencia a la Tierra, que se da en virtud de la intimidad:

H. MujicA, La palabra inicial, 97.

12 F. Hölderlin, citado en M. Heidegger, "Como cuando en día de fiesta", en Aclaraciones a la poesía de Hölderlin (Alianza Editorial, Madrid 2005) 56.

13 M. Heidegger, "Hölderlin y la esencia de la poesía", en Aclaraciones a la poesía de Hölderlin (Alianza Editorial, Madrid 2005) 38.

14 F. Hölderlin, citado en M. Heidegger, "Hölderlin y la esencia...", 40. 
aquello que, a la vez, separa y reúne a todas las cosas, en armonía discordante. Testimoniar la pertenencia a la Tierra como intimidad, según Heidegger, pasa por la apertura de mundo, pero también por la destrucción y el hundimiento del mismo. Creación y apertura, destrucción y hundimiento, son movimientos de la libertad desplegada en la historia. El lenguaje es, pues, ámbito de la decisión libre, apertura de la existencia histórica del hombre como perteneciente a la Tierra, como creador y destructor. Solo donde hay lenguaje hay mundo e historia; por tanto, solo donde hay lenguaje puede tener lugar la acción humana como obra y responsabilidad, pero también como arbitrariedad, ruido y confusión.

El lenguaje es el propiciador de todo peligro, puesto que, al tiempo que guarda la posibilidad de conservar una relación creativa con todas las cosas, en la que estas descansen en su propia esencia, implica también la posibilidad de pérdida de esta esencia, del ser mismo. El peligro que aquí se menciona consiste justamente en que en el lenguaje se guarda la posibilidad de amenaza al ser por parte del ente. El lenguaje oculta y muestra; es en el lenguaje donde se oculta el ser; es allí donde acontece propiamente su olvido cuando la mirada se detiene en el ente y en su exigencia de fundamentación óntica (tal como ha sido la mirada de la metafísica y la ciencia), sin advertir el horizonte que hace posible la aparición de todo ente y que, situándolo en la mutua pertenencia entre ser, entes y lenguaje, lo conduce a lo propio, a su dimensión esencial. Tanto el olvido característico de la entificación metafísica y técnica como el aparecer fundado en lo esencial de la palabra poética acontecen en el lenguaje. De ahí la necesidad del pensamiento y del poetizar como búsqueda de un decir que no entifique al ser, que lo deje aparecer en su extrañeza y diferencia respecto del ente, situando a este ente en lo que le es más propio: la intimidad de la relación entre las regiones del Cuarteto: Cielo y Tierra, Celestiales y Mortales. Tal relación auténtica con el lenguaje es la disposición pensante de la poesía que se pone a la escucha del silencio del ser mismo, posibilitando su audibilidad y el abrirse del mundo como discurrir del tiempo, concurrencia de los dioses y aparecer de las cosas.

El cuarto lema: "Pero lo que permanece lo fundan los poetas"15 se refiere, según Heidegger, a la fundación del ser en la palabra. El poeta se pone a la escucha y es así como en su palabra el ser acontece como

15 F. Hölderlin, citado en M. HeidegGer, "Hölderlin y la esencia...”, 45. 
aparecer de los entes y los dioses en su esencia, en lo que les es propio. El poeta no nombra algo previamente existente, sino que los entes y los dioses aparecen por primera vez gracias a la palabra como libre ofrecimiento del poeta. No obstante, este libre ofrecimiento, que es creación (póiesis), no se fundamenta en el capricho de la voluntad autónoma sino en el destino poético signado por el ser mismo en el lenguaje. Es el lenguaje, en cuanto Decir esencial (Sage), el que, diciéndose en la palabra poética, lleva a los entes al desocultamiento. Heidegger afirma que los dioses llegan a la palabra, se presentan gracias a ella, pero son los dioses mismos los que nos conducen a la palabra "[...] cuando ellos mismos empiezan por interpelarnos y nos ponen bajo su interpelación" ${ }^{16}$. Heidegger sostiene que los dioses no son una consecuencia del acontecimiento del lenguaje, sino que la apertura de mundo, la presencia de los dioses y el acontecimiento del lenguaje son una y la misma cosa, y se dan simultáneamente. Tiempo y existencia histórica, dioses y lenguaje se dan como acontecimiento esencial y originario de mundo. Aquí se enuncia claramente, entonces, la conexión entre la búsqueda de un camino que nos oriente hacia la esencia del lenguaje, y la dimensión de los dioses y lo sagrado, que nos interpelan desde el ámbito esencial del lenguaje. De modo que la escucha atenta del Decir esencial del ser es también escucha atenta de la interpelación de los dioses.

Hölderlin es el poeta del poeta y es, además, el poeta de lo sagrado. El interés de Heidegger por Hölderlin concierne, de modo ineludible, al asunto de lo sagrado, lo divino y los dioses en su relación con el lenguaje. Dicho de otro modo, pensar el ser como Cuaternidad siguiendo la poesía de Hölderlin, es decir, como apertura de mundo propiciada a partir de las cuatro regiones: Cielo y Tierra, Celestiales y Mortales, nos convoca a preguntarnos por el lugar de los dioses y lo sagrado en el contexto de este pensamiento. ¿Qué relación guarda, además, el asunto de lo divino, los dioses y lo sagrado con la reflexión sobre el lenguaje y el silencio y sobre la posibilidad de un lenguaje no metafísico, tal como veníamos esbozándolo a partir de De un diálogo acerca del habla? Para abordar esta pregunta en torno al lenguaje, el silencio y lo sagrado -lo divino, los dioses y Dios-, aprovecharemos la interpretación que sobre estos temas ha llevado a cabo el profesor Néstor Corona, con el fin de puntualizar ciertos aspectos particulares que nos permitirán, luego, con-

$\overline{16}$ M. Heidegger, "Hölderlin y la esencia...", 45. 
traponer esta interpretación a la realizada por Jean-Luc Marion. Esperamos que esta contraposición sitúe mejor el lugar del pensamiento de Marion en relación con Heidegger, para así introducir el propio pensamiento del filósofo francés sobre Dios, el lenguaje y el silencio.

\section{SOBRE EL ASUNTO DE LO DIVINO Y DE DIOS EN HEIDEGGER}

En el texto La cuestión de Dios en Heidegger: metafísica, pensamiento del ser, pensamiento según la poesía ${ }^{17}$, de Néstor Corona, se aborda la relación de Heidegger con lo sagrado, lo divino, los dioses y Dios a partir de un análisis que se desarrolla conforme a diferentes momentos de su pensamiento (que no se plantean aquí en estrictos términos cronológicos, sino más bien de forma metodológica). El primero de estos momentos corresponde al pensamiento de la diferencia ontológica. El segundo momento es el pensamiento que se pone a la escucha de la poesía y que, por esta vía, llega a la comprensión del ser como Cuaternidad. Por último, el tercer momento, imbricado íntimamente con los dos anteriores, tendría como texto paradigmático la conferencia Tiempo y ser (Zeit und Sein), donde ya no se pensaría lo Ereignis, según Néstor Corona, como ser-tiempo-lenguaje, sino como el Ello que da ser-tiempo-lenguaje. El desarrollo de los momentos mencionados está atravesado, además, por la pregunta sobre la cercanía y la distancia que el pensador alemán concibe entre el pensamiento y la poesía. Sobre esta pregunta podemos adelantar que, como concluye el autor en su artículo, el camino del pensamiento y el de la poesía (relacionado este último con la religión) practicarían de un modo divergente la experiencia de lo mismo. Un pasaje como el siguiente podría servir para apoyar esta idea de Néstor Corona. Aquí, Heidegger resalta la cercanía esencial entre la filosofía -o pensamiento-, el arte y la religión, sin que esto conlleve su plena identificación: "La comparación [de la filosofía -o del pensamiento-] con el arte y la religión [...] es una equivalencia justificada y necesaria de su esencia. Pero equivalencia no quiere decir aquí uniformidad" ${ }^{18}$.

17 N. Corona, "La cuestión de Dios en Heidegger: metafísica, pensamiento del ser, pensamiento según la poesía”, en Teología y Vida, 49 (2008) 251-277. Recuperado de http://www.redalyc.org/articulo.oa?id=32214686004

18 M. Heidegger, citado en B. Onetto, Inflexiones preparatorias al pensamiento del inicio. Pensar y poetizar en el pensamiento heideggeriano (2001) 78. Recuperado de https://www.academia.edu/1385380/Inflexiones_preparatorias_al_pensamiento_del_inicio._Poetizar_y_pensar_en_el_pensamiento_heideggeriano._2001 
A fin de abordar la interpretación de Corona, considerando los momentos antes señalados, empecemos por recordar que Heidegger quiere llevar a cabo una crítica de la metafísica entendida como olvido del ser en el horizonte de la objetualidad, es decir, una crítica a la pretensión de fundamentar el ente desde el ente mismo. Esta pretensión guía toda pregunta por la causa, por el por qué, bajo el principio de razón. De tal exigencia de fundamentación óntica del ente surge la onto-teología: la concepción de un ente supremo como fundamento de todo ente. El pensamiento del ser en su diferencia respecto a los entes (diferencia ontológica) conduce a Heidegger a una crítica del Dios metafísico, que es el Dios de la filosofía y de la teología metafísica cristiana. Dice Heidegger:

Quien ha experimentado la teología, tanto de la fe cristiana como la de la filosofía, en su plenitud de desarrollo, hoy prefiere callar en el ámbito del pensar de Dios. Pues el carácter onto-teológico de la metafísica ha devenido cuestionable para el pensamiento, no sobre la base de algún ateísmo, sino a partir de la experiencia de un pensar al cual en la onto-teo-logía se le ha mostrado la unidad aún impensada de la esencia de la metafísica ${ }^{19}$.

Además, afirma Heidegger:

Conforme con ello, el pensar sin Dios (das gottlose Denken), el que debe abandonar el Dios de la filosofía, el Dios como Causa sui, se halla quizás más cercano al Dios divino. Esto solo quiere decir: es más libre para él, que lo que quisiera ver la onto-teo-logía $a^{20}$.

Según Néstor Corona, el pensamiento de la diferencia ontológica lleva a Heidegger a experimentar la necesidad de otro lenguaje para pensar el ser por fuera de la metafísica. Este lenguaje es buscado en la poesía y, de modo sobresaliente, en la poesía de Hölderlin. Desde Hölderlin, Heidegger piensa el ser como mundo-Cuarteto, conformado según cuatro regiones: el Cielo y la Tierra, los Celestiales y los Mortales. Esta mención al pensamiento que se pone a la escucha de la poesía nos permite situarnos en el contexto del artículo "...poéticamente habita el hombre..."21. Allí se habla del destino del poeta en términos de una toma de medida, que abre la dimensión del mundo y lo hace habitable por el hombre. El

\footnotetext{
19 M. Heidegger, citado y traducido en N. Corona, "La cuestión de Dios...", 256.

20 M. Heidegger, citado y traducido en N. Corona, "La cuestión de Dios...", 256.

21 M. Heidegger, “...poéticamente habita el hombre...”, en Conferencias y artículos (Ediciones del Serbal, Barcelona 1994) 163-178.
} 
referente de esta toma de medida son los aspectos del Cielo en los que el Dios desconocido se envía o se destina a lo extraño, que es lo familiar del hombre. Dice Heidegger:

[...] [E]l poeta, si es poeta, no describe el mero aparecer del cielo y de la tierra. El poeta, en los aspectos del cielo, llama a Aquello que, en el desvelarse, hace aparecer precisamente el ocultarse, y lo hace aparecer de esta manera: en tanto que lo que se oculta. El poeta, en los fenómenos familiares, llama a lo extraño como aquello a lo que se destina lo invisible para seguir siendo aquello que es: desconocido ${ }^{22}$.

En los fenómenos del Cielo y de la Tierra el poeta nombra y llama, para decirlo en términos de Hölderlin, a las "fuerzas siempre vivas de los dioses". Estos fenómenos son imágenes, que "[...] deja[n] ver el aspecto de lo invisible y de este modo lo mete[n] en la imagen de algo extraño a él" ${ }^{23}$. La imagen es lo extraño del Desconocido en lo que este se envía, se revela, manteniéndose en el ocultamiento como el Desconocido. El Dios desconocido no estaría en la misma posición de los dioses -los Celestes- y del Cielo, que fijan la medida del Entre del mundo y de lo humano que, según Heidegger, le corresponde tomar al poeta:

[...] [E]l dios desconocido aparece como el desconocido por medio de la revelabilidad del cielo. Este aparecer es la medida con la que el hombre se mide. [...] Avistar esta medida, sacar la medida de esta medida y tomarla como la medida quiere decir para el poeta: poetizar. El poetizar es esta toma-de-medida, y además para el habitar del hombre ${ }^{24}$.

Los dioses y los fenómenos del Cielo son nombres familiares con los que el poeta nombra y canta lo que permanece siempre lejano y oculto para él. El Dios desconocido no se sitúa, según Néstor Corona, dentro del ser-Cuarteto-mundo, sino que se envía a él desde un más allá del ser que, como tal, es irrepresentable e impensable. Dios y Desconocido son nombres que no nombran aquello que no podemos representarnos. Aunque el poeta canta y llama en los fenómenos familiares a lo invisible, lo invisible mismo constituye el encuentro límite con el silencio y el misterio. Dice Néstor Corona:

22 M. HeidegGer, “...poéticamente habita el hombre...”, 174-175.
23 M. Heidegger, “...poéticamente habita el hombre...”, 175.
24 M. Heidegger, “...poéticamente habita el hombre...”, 172-173. 
Dios se manifiesta ocultándose "tras» aquellos que hacen señas hacia él; los Divinos no son Dios, son sus «figuraciones», «imaginaciones» (Ein-bildungen) -vale repetir: Dios mismo no se hace presente-, que en sus figuras señalan hacia el Invisible. Heidegger habla de la «palpitante ausencia de Dios» y del "permanente acercarse del Lejano» ${ }^{25}$.

Además, afirma:

[...] [S] i el Cuarteto es el nuevo nombre del ser -su rostro familiar y más originario-, y sus Divinos remiten más allá, al Dios oculto y retirado en su intimidad, corresponde pensar, volviendo a la terminología del pensamiento del ser y el ente, que Dios se halla más allá del ser (Cuarteto) -y en la Carta [sobre el Humanismo] Heidegger había advertido que el ser no es Dios- ${ }^{26}$.

Por otra parte, para el profesor argentino, lo Ereignis como Es gibt, el Ello que da ser, tiempo, lenguaje, y los apropia el uno al otro y a sí mismo, no se identifica ni con el ser, ni con el tiempo, ni con el lenguaje, ni tampoco con el dar (vale la pena aclarar que Corona precisa que el sentido de lo Ereignis en los Beiträge no sería todavía el de Tiempo y ser, en los Beiträge, Ereignis se referiría a la mutua pertenencia ser-pensamientotiempo ${ }^{27}$ ). Una afirmación de Heidegger que parecería corroborar lo dicho por Corona es la siguiente: "Si pensamos propiamente el ser, la cosa misma nos lleva en cierto modo fuera del ser (vom Sein weg), y pensamos el destino (das Geschick) que da el ser como don"28. Recogiendo esta interpretación, Corona sintetiza:

[...] Ereignis nombra el acontecimiento del dar -ya él más allá del ser-sentido- como siguiéndose de un Donador que así nombrado, sin embargo, en lo suyo más íntimo no es alcanzado por tal nombre. Lo que dona, dicho precisamente, está más allá, como tal, de $s u-\sin$ embargo-donar: ese el que, lo que, se sustrae a toda nominación (es el Ello de la expresión «Es [Ello] gibt»); su nombre más propio no es siquiera Donador ${ }^{29}$.

Néstor Corona resalta que, para Heidegger, no se trata de una mística, y es claro en afirmar que Heidegger no dice que lo Ereignis, así pensado desde el pensar del ser y desde el pensar que sigue a la poesía,

25 N. Corona, "La cuestión de Dios...", 263.

26 N. Corona, "La cuestión de Dios...", 263.

27 N. Corona, "La cuestión de Dios...", 274.

28 N. Corona, "La cuestión de Dios...", 268.

29 N. Corona, "La cuestión de Dios...", 269. 
sea Dios. Sin embargo, este autor acaba por plantear que tanto el poeta y el hombre religioso como el pensador llegan a la experiencia límite del silencio ante lo irrepresentable, inabarcable e indecible que es, para los primeros, el Dios desconocido y, para el segundo, lo Ereignis. El pensamiento, ante esto último, calla. Pero es un callar que se constituye, de un modo eminente, al permitir aparecer en el decir "lo no dicho y por cierto como tal". Por su parte, el poeta y el hombre religioso están llamados a cantar y nombrar, también con "nombres que no nombran", con nombres divinos y a partir de lo familiar, al siempre Lejano, a Dios. "El silencio del poeta es vencido por el nombre Dios; este nombre Dios queda sin embargo siempre envuelto en la atmósfera del silencio"30.

Así pues, el pensamiento y la poesía -como la religión, entiéndase no metafísica- se encuentran en la misma experiencia límite del silencio, aunque lo que le es dado practicar a cada uno ante esta experiencia es divergente. Sería posible, entonces, pensar así la cercanía de la que habla Heidegger -cercanía que guarda la lejanía- entre el pensar sin Dios y el Dios divino. Por último, se pregunta Néstor Corona: “¿No callan entonces poetas y pensadores ante lo mismo; el poeta nombrándolo y callándolo a la vez como Dios (desconocido) y los pensadores como Ereignis -y los demás nombres que, como Ereignis y Ello, invitan al silencio-?”31.

Para pensar algunas características del decir y el callar de la poesía, podríamos recordar un fragmento del profesor Breno Onetto:

Los poetas son, para Heidegger, los que respondiendo a [las] señas del lenguaje divino, las mantienen rigurosamente ocultas en la palabra, en sus imágenes. Y lo hacen permitiéndonos oír lentamente lo indicado en el poema. Oír al poema quiere decir, atender a las imágenes de proximidad y lejanía de lo divino; imágenes que no deben aclararse, sino antes bien ocultarse; no hacer de lo dicho algo corriente, ordinario, sino algo raro, singular; no acercar, sino poner en la lejanía; y esto tanto más oscile en el temple fundamental de la poesía y, a una con ella, el destino de un pueblo y su relación con los dioses. (...). Palabras de un pensar que requieren por un lado de este decir, pero que no se realizan en él. El pensar no tiene parada en el ente, puesto que piensa el Ser. No halla ejemplaridad en lo pensado, ya que lo pensado piensa el ente. El decir del pensar es a diferencia de la palabra poética lo carente de imagen. Y donde parece darse

30 N. Corona, "La cuestión de Dios...", 273.

31 N. Corona, "La cuestión de Dios...”, 273. 
una imagen, no es ni lo poetizado de un poema ni lo intuido de un sentido, sino solo la anclada esperanza de una osada y desafortunada falta de imágenes ${ }^{32}$.

En el fragmento, Onetto dice que la imagen muestra, pero manteniendo en la lejanía, en la reserva del ocultamiento, lo divino mismo. Recordemos lo dicho por Heidegger en "...poéticamente habita el hombre...": "El poeta, en los aspectos del cielo, llama a Aquello que, en el desvelarse, hace aparecer precisamente el ocultarse, y lo hace aparecer de esta manera: en tanto que lo que se oculta" ${ }^{33}$. La imagen "[...] deja ver el aspecto de lo invisible y de este modo lo mete en la imagen de algo extraño a él"34. Siguiendo la línea interpretativa de Néstor Corona, se podría decir que, en el juego de la mostración y el ocultamiento que hace posible la imagen, el poeta nombraría a partir de nombres-imágenes que no reducen lo nombrado a la presencia, y, por lo tanto, no lo entifican. El nombre-imagen del poeta guardaría la excedencia infinita de la invisibilidad, la extrañeza, y, por lo tanto, la distancia insuperable entre lo que permanece oculto y aquello que se muestra en los aspectos del Cielo y de la Tierra. Así entendida, la imagen poética no se detendría en el ente, sino que señaría, para utilizar la expresión heideggeriana, hacia la invisibilidad siempre desconocida y propiamente incognoscible. Nos queda abierta la pregunta por el sentido de la necesidad que experimenta el pensamiento, en cuanto que lenguaje sin imágenes, de seguir el lenguaje con imágenes de la poesía.

¿Podemos, entonces, asumir que, cuando el poeta trata con las imágenes de los aspectos del Cielo, preserva al Dios desconocido en su ocultamiento y distancia y, por lo tanto, no lo retiene en el ámbito entitativo de la Cuaternidad? ¿Dios es también aquí un ente, como en la metafísica? ¿O habría en Heidegger un intento, si no de pensarlo explícitamente, sí de indicar hacia un posible pensamiento no metafísico, es decir, no onto-teológico de Dios, en el que este se halle libre de la condición de ente dada en el espacio de la Cuaternidad, tal como se deriva de la interpretación del profesor Néstor Corona? ¿Encuentra Heidegger en la poesía la real posibilidad de un lenguaje no metafísico? Lo que está en juego en esta decisión no es de poca monta, sino que atañe justamente

32 B. ONETTO, Inflexiones preparatorias..., 87-88.

33 M. Heidegger, “...poéticamente habita el hombre...”, 174-175.

34 M. Heidegger, “...poéticamente habita el hombre...”, 175. 
a la cuestión del pensamiento del ser como intento de superación de la metafísica y, en este contexto, al asunto del lugar ocuparían Dios y lo sagrado en este pensamiento del nuevo comienzo. Por lo menos llamaría la atención que en un camino de pensamiento tensado en la crítica a la tradición metafísica onto-teológica occidental se retenga lo divino y a Dios en su condición entitativa, es decir, onto-teológica. Más aún, en cierto sentido, por esto, el pensamiento de Heidegger quedaría él mismo retenido, en lo concerniente a un asunto capital, dentro de las márgenes de la onto-teología, es decir, de la metafísica ${ }^{35}$. Podría argumentarse que la onto-teología no consiste tanto en la afirmación "Dios es un ente" como en el intento de fundamentación de lo ente a partir de un summum ens o causa sui. O para decirlo con mayor precisión, la ontoteología consistiría en la identificación y la confusión entre el ser y Dios que hace curso en diversos momentos de la historia de la filosofía. Sin embargo, podemos sostener que la concepción de Dios como ente es la base indefectible sobre la cual se erige la estructura onto-teológica, que identifica al ser con Dios en cuanto que ente supremo y causa última de todos los entes. Por esto, la comprensión de Dios como ente sigue, en su matriz fundamental, el presupuesto onto-teológico y metafísico. Como veremos, hay elementos suficientes para sostener, contra la interpretación de Corona, que en el pensamiento de Heidegger les es conferido un lugar a Dios o a los dioses, en la apertura de mundo como Cuaternidad, en el que estos aparecen como entes, sostenidos en la intimidad de la región cuaterna. Esto lo confirma el mismo Heidegger cuando afirma en su ensayo La vuelta: "[...] pues el Dios también es, si es que él es, un ente; en cuanto ente, está en el Ser y su esencia, que se acontece-apropia desde el mundear del mundo" 36 .

En cuanto que el pensamiento, el arte y la religión, sin ser intercambiables entre sí, reconducen a una "[...] equivalencia justificada y necesaria de su esencia" ${ }^{\prime \prime}$, podemos preguntarnos si la posibilidad de un lenguaje no metafísico solo se encuentra dada en el ámbito del pensamiento y, en Heidegger, fundamentalmente en el ámbito de la poesía. $\mathrm{O}$ si es dado concebir asimismo la posibilidad de un lenguaje tal, sobre

35 Cfr. C. E. Restrepo, "La marca onto-teológica de la metafísica”, en La remoción del ser. La superación teológica de la metafísica (San Pablo, Bogotá 2012) 33-79.

36 M. Heidegger, "La vuelta (Die Kehre)", en Filosofía, ciencia y técnica (Editorial Universitaria, Santiago de Chile 1997) 193.

37 M. Heidegger, citado en B. OnetTo, Inflexiones preparatorias..., 78. 
todo, en el ámbito de la religión, de modo que Dios no siga siendo pensado dentro de las condiciones, en definitiva limitadas, del despliegue de mundo como Cuaternidad.

Jean-Luc Marion nos permitirá aproximarnos a esta posibilidad de un pensamiento de Dios no condicionado al ser. Enfrentado al asunto de Dios y el ser en Heidegger -asunto que él reconoce como polémi$\mathrm{Co}^{38}-$, Marion se distancia, como veremos, del camino interpretativo trazado por Néstor Corona, para llegar a afirmar la preeminencia y anterioridad en Heidegger del ser sobre Dios y, por lo tanto, la reafirmación de la condición onto-teológica de Dios como un ente, lo cual implica afirmar, en el sentido en que lo hemos dicho, que incluso el pensamiento del nuevo comienzo heideggeriano permanecería anclado, de algún modo, a la onto-teología.

Nuestra intención es resaltar la distancia del pensamiento de Marion respecto al de Heidegger en algunos de los asuntos capitales que hemos mencionado y subrayado ya desde la lectura realizada por Néstor Corona. Para esto, quisiéramos atender a las posibilidades que ofrece Marion de pensar al Dios de la revelación como amor ("Quien no ama no ha conocido a Dios, porque Dios [es] agápe” 1 Juan 4, 8), y, por lo tanto, como lo impensable mismo. A partir de estas indicaciones buscamos, además, preguntarnos de qué manera se juega en todo ello la posibilidad de concebir la relación entre el lenguaje, el silencio y Dios en correspondencia con el ser del hombre, desde el amor, de un modo no metafísico, en la oposición que este autor plantea frente al pensamiento heideggeriano del nuevo comienzo.

\section{MARION: LA INTERPELACIÓN DE LA DISTANCIA}

En Dios sin el ser, Marion comienza introduciendo una dupla de términos que le permitirán pensar lo que él llama la concepción idolátrica de Dios propia de la metafísica, así como la posibilidad de un pensamiento no idolátrico, es decir, no metafísico. Estos términos son el ídolo y el icono.

El ídolo y el ícono no son dos clases de entes, sino más bien dos modos de ser de los entes. Ambos conciernen a lo divino, pero de un modo distinto. Tanto el ídolo como el icono no se reducen a la pura

38 J. L. MARion, Dios sin el ser (Ellago Ediciones, Vilaboa, Pontevedra 2010) 79, nota 23. 
inmanencia de su visibilidad, como sucede con las "artes de adorno", puesto que son signa que señalan hacia otro término. La diferencia entre ellos radica más bien en su modo de señalar hacia lo divino, en su modo de hacerlo visible, dado que la variación en el régimen de visibilidad de uno y otro implica una variación en el modo de "aprehender" lo divino mismo: "[L]a manera de ver decide lo que se puede ver o, más bien, al menos negativamente, decide lo que, en todo caso, no podrá percibirse de lo divino" 39 . El ídolo es una representación de lo divino a la medida de la mirada humana que, en consecuencia, hace posible su aprehensión cognoscente. El ídolo fascina y retiene la mirada en su esplendor y en su familiaridad, aun monstruosa, impidiéndole avanzar más allá de su propio aparecer, porque no admite la invisibilidad. La mirada constituye intencionalmente al ídolo como su objeto de conocimiento y satisfacción, y en él se detiene y se regodea. Por su parte, el ídolo, en cuanto que representación, fija la mirada estableciendo su límite y su alcance. El ídolo es reflejo, por lo tanto, de la capacidad de la mirada: es "[e]se dios cuyo espacio de manifestación se mide por lo que una mirada puede soportar [...]”40. El ídolo se ancla, pues, según Marion, en una particular experiencia de lo divino que quiere ser fijada como definitiva.

Pero no solo hay ídolos sensibles, sino también ídolos conceptuales. El concepto (concipere, capere) es la captación en un signo de lo aprehensible por el espíritu en un momento dado. La mirada del espíritu produce conceptos de lo divino, variables según su capacidad, que no pueden reflejar, en último término, la amplitud de lo divino mismo. La llamada Teología negativa, o Teología mística, es, en definitiva, una advertencia de este límite de la mirada y de la imposibilidad de alcanzar desde las categorías humanas tal amplitud. Dionisio Areopagita afirma: "Ningún razonamiento puede alcanzar aquel Uno inescrutable. No hay palabras con que poder expresar aquel Bien inefable [...]. Trasciende toda razón, toda intuición, todo nombre [...]. Él mismo está fuera de las categorías del ser” ${ }^{41}$. Por su parte, Marion señala:

Cuando un pensamiento filosófico enuncia un concepto sobre lo que nombra en ese momento "Dios», dicho concepto funciona exacta-

\footnotetext{
J. L. Marion, Dios sin el ser, 27.

J. L. MARIOn, Dios sin el ser, 33.

41 Dionisio Areopagita -Pseudo, Obras completas (Biblioteca de Autores Cristianos, Madrid 1990) DN 588 B.
} 
mente como un ídolo: se da a ver pero, de ese modo, se disimula tanto mejor como el espejo en el que el pensamiento, invisiblemente, recibe la localización de su avance; y ello de tal manera que lo no- mentado resulta descalificado y abandonado, con una mención suspendida por el concepto fijado; el pensamiento se paraliza y aparece así el concepto idolátrico de «Dios», en el que se está juzgando precisamente el pensamiento mismo y no a $\operatorname{Dios}^{42}$.

Todo ateísmo exige el establecimiento previo de un concepto limitado y regional de Dios, sobre el cual el pensamiento pueda ejercer el acto de negación. Todo ateísmo parte, como condición previa, de la constitución de un ídolo. Así, la "muerte de Dios" ha de comprenderse, según el mismo Nietzsche, como la muerte del Dios moral: "Im Grunde ist ja nur der moralische Gott überwunden, en el fondo solo el Dios moral ha sido superado" ${ }^{43}$. Es decir, lo que allí se anuncia es la muerte de un particular concepto de Dios.

Por su parte, el icono no es constituido por la visión, sino que la constituye; en él se da lo invisible a la visibilidad, pero permaneciendo como tal invisible. El icono no se dispone conforme a la medida de la mirada; dispone a la mirada a la medida de la desmesura. En él, lo visible nunca se cierra sobre sí mismo, deteniendo la mirada en su visibilidad, sino que hace remontar a la mirada de visible en visible, relanzándola insistentemente hacia la profundidad infinita: "[...] [E]l icono no se hace visible más que suscitando una mirada infinita" ${ }^{4}$. En este contexto habría que comprender la afirmación de San Pablo: Cristo es "Icono del Dios invisible, eikôn tou theou tou aoratou" (Colosenses 1, 15), puesto que en Cristo, aunque revelado, lo invisible permanece invisible.

Del mismo modo que hay ídolos conceptuales, también puede concebirse un concepto icónico que solo puede ser tal al renunciar a la pretensión de captar lo que no puede ser captado y de comprender lo incomprensible:

[Un concepto así debe] dejarse medir por la desmesura de lo invisible que entra en la visibilidad mediante la profundidad infinita, es decir,

42 J. L. Marion, Dios sin el ser, 35.

43 F. Nietzsche, citado en J. L. Marion, Dios sin el ser, 36.

44 J. L. Marion, Dios sin el ser, 38. 
un concepto que diga o prometa decir esa profundidad infinita en la que lo visible y lo invisible se familiarizan ${ }^{45}$.

Marion toma como vía de aproximación a lo que puede significar un icono conceptual la idea infiniti cartesiana: "Para tener una idea verdadera del infinito, este no debe de ninguna manera ser comprendido, por cuanto la incomprensibilidad misma está contenida en la razón formal del infinito" ${ }^{46}$. Entre la idea y lo que ella indica hay una inadecuación esencial, una distancia infinita, y solo gracias a esta distancia el concepto puede legitimarse en cuanto que icono. "[...] [E]l icono obliga al concepto a recibir el recorrido de la profundidad infinita" ${ }^{47}$. Lo indicado a través del concepto es la intención de la distancia que se envía a lo visible para propiciar el reenvío de lo visible a lo invisible. Este envío y reenvío es el recorrido infinito e indeterminable por medio del concepto.

Ahora bien, Marion hace una reconstrucción de la estructura ontoteológica de la metafísica, estructura que estaría basada en la exigencia de fundamento óntico que acaba conduciendo a una concepción de Dios como causa sui y como summum ens. Este es el Dios de los filósofos: el Dios que aparece a la sombra de la metafísica como condición y espacio determinativo para su aparición. Tal como lo afirma Heidegger, el Dios legitimado dentro del espacio de la metafísica no soporta ni el culto ni la adoración: "A ese Dios, el hombre no puede ni rezarle ni hacerle sacrificios. Ante la causa sui, el hombre no puede temeroso caer de rodillas, ni tampoco tocar instrumentos, ni bailar” ${ }^{\prime 8}$. En oposición a este ídolo conceptual de la metafísica, Marion recuerda la siguiente afirmación de Bossuet: "nuestro Dios [...] está infinitamente por encima de la Causa primera y de ese primer motor que los filósofos han conocido sin, no obstante, adorarlo" 49 .

Superar el concepto de Dios como causa sui, característico de la ontoteología metafísica, ¿podría propiciar un pensamiento no metafísico de Dios? Ciertamente, para Marion, un ídolo puede ser sucedido por otro: los "nuevos dioses" de Nietzsche son forjados por la voluntad de po-

\footnotetext{
45 J. L. Marion, Dios sin el ser, 43.

46 Descartes, citado en J. L. Marion, Dios sin el ser, 44, nota 18.

47 J. L. Marion, Dios sin el ser, 44.

48 M. Heidegger, citado en J. L. Marion, Dios sin el ser, 63.

49 J. Bossuet, citado en J. L. Marion, Dios sin el ser, 65.
} 
der, expresada como "instinto creador de dioses"50 ¿ ¿Entraña el nuevo comienzo heideggeriano una posibilidad de concebir al Dios divino, es decir, al Dios liberado de todo condicionamiento dado por categorías finitas? Según Marion, a diferencia de Néstor Corona, el aparecer de Dios en el pensar del nuevo comienzo está supeditado a las condiciones del ser, lo que implica concebirlo como ente. Este asunto resulta tan decisivo que Marion se empeña en citar diversos pasajes de la obra de Heidegger que apoyan su interpretación.

En primer lugar, Marion recurre al famoso fragmento de la Carta sobre el humanismo, donde Heidegger afirma:

Solo a partir de la verdad del Ser se puede pensar la esencia de lo sagrado. Solo a partir de la esencia de lo sagrado se puede pensar la esencia de la divinidad. Solo a la luz de la esencia de la divinidad puede ser pensado y dicho qué debe nombrar la palabra «dios» ${ }^{51}$.

Pero lo sacro, que es el único espacio esencial de la divinidad, que es también lo único que permite que se abra la dimensión de los dioses y el dios, solo llega a manifestarse si previamente, y tras largos preparativos, el ser mismo se ha abierto en su claro y llega a ser experimentado en su verdad ${ }^{52}$.

En principio, se podría considerar que esta serie jerárquica no se está pensando necesariamente en relación con Dios, sino en relación con el Dasein. Es decir, la verdad del Ser, lo sagrado y lo divino serían condiciones, no para Dios, sino para liberar el pensamiento del Dasein de su estructura metafísica, diríamos de sus ídolos, en suma, de lo que no es Dios - dicho con un recurso cercano a la Teología negativa-. Así, como dice Heidegger, el pensar sin Dios se hallaría más próximo al Dios divino, y, quizás, más libre para él ${ }^{53}$.

Entre las múltiples citas de Heidegger retomadas por Marion, quisiera considerar al menos otras dos. La primera resulta especialmente discutible porque parece desentonar en el conjunto, sirviendo de apoyo a la interpretación arriba esbozada. Afirma Heidegger:

\footnotetext{
50 J. L. Marion, Dios sin el ser, 67.

51 M. Heidegger, "Carta sobre el humanismo", en Hitos (Alianza Editorial, Madrid 2001) 287.

52 M. Heidegger, “Carta...”, 278.

53 M. Heidegger, citado en J. L. Marion, Dios sin el ser, 63.
} 
No puedo ser más reservado ante toda tentativa de emplear el Ser para determinar teológicamente en qué Dios es Dios. Del Ser no hay aquí nada que esperar. Yo creo que el Ser no puede ciertamente ser pensado nunca en la raíz y como esencia de Dios; sin embargo, la experiencia de Dios y su manifestabilidad, en cuanto esta puede alcanzar al hombre, fulgura en la dimensión del Ser, lo que de ninguna manera significa que el Ser pueda tener el sentido de un predicado posible para $\operatorname{Dios}^{54}$.

Heidegger parecería indicar con mayor claridad que de Dios no es posible decir que sea. Que el ser no puede tener el sentido de un predicado para Dios significaría que no puede decirse que Dios es (un ente). Por lo tanto, Heidegger se limitaría a confirmar que la experiencia humana de Dios acontece en la dimensión del ser. Esto no significaría necesariamente que se someta a Dios mismo a las condiciones del Dasein. Más bien, siguiendo la lectura del profesor Corona, podría entenderse que la manifestabilidad que aquí se menciona aludiría a la participación de lo infinito en lo finito en la que lo infinito mismo se mantiene a la distancia como infinito. Dios se envía al hombre: encierra su infinitud dentro de nuestras limitaciones, manteniéndose, no obstante, en la distancia infinita ${ }^{55}$. Dios no podría ser pensado, según el fragmento, desde el Ser como su raíz.

A pesar de esto, una afirmación como la siguiente resulta contundente y bloquea, en definitiva, una línea interpretativa como la de Néstor Corona. Afirma Heidegger en su ensayo La vuelta: "[...] pues el Dios también es, si es que él es, un ente; en cuanto ente, está en el Ser y su esencia, que se acontece-apropia desde el mundear del mundo" ${ }^{56}$. Este otro fragmento lo confirma:

Que el Dios viva o que siga muerto, no se decide ni por la religiosidad de los hombres ni, aun menos, mediante las aspiraciones teológicas de la filosofía y de la ciencia natural. Que Dios es Dios se acontece-apropia desde la constelación del Ser y dentro de ella ${ }^{57}$.

En último término, y más allá de las ambigüedades que suscita el mismo pensamiento heideggeriano, Dios es comprendido por el pensa-

54 M. Heidegger, citado en J. L. Marion, Dios sin el ser, 70, nota 23.

55 Dionisio Areopagita -Pseudo, Obras completas, DN 588 A.

56 M. HeidegGer, "La vuelta...", 193.

57 M. Heidegger, “La vuelta...”, 194. 
dor alemán como ente que aparecería cobijado por la constelación del ser, dentro del despliegue de la mutua pertenencia entre ser y entes como Cuaternidad o acontecer de mundo propiciado por el acontecimientoapropiador (Ereignis). Esto a pesar de otros fragmentos ya vistos donde se induciría a pensar a Dios de un modo más originario (tal como lo vimos en la exposición de Néstor Corona). Así pues, más originario que Dios sería el acople de tiempo-espacio-lenguaje, esto es, el mundo como Entre medido y fundado en la palabra por el poeta. Más originario que Dios sería lo Ereignis como acontecimiento-apropiador de tiempoespacio-lenguaje $\mathrm{e}^{58}$. Sobre esto, Marion plantea:

Pero, ¿va de suyo que Dios tenga que ser y, en consecuencia, ser en tanto que ente (supremo, plural o como se quiera) para darse como Dios? ¿De dónde viene que el Ser se encuentre admitido sin cuestionamiento alguno como el templo abierto de antemano (o cerrado) a toda teofanía pasada o por venir? Y, al contrario, ¿no se podría incluso sospechar que el templo del Ser, por definición y axioma del pensamiento del Ser como tal, no puede en ningún sentido ni socorrer, ni apelar, ni admitir, ni prometer sea lo que sea respecto a lo que no habría ni siquiera que nombrar -Dios? [...] Sin duda, si «Dios» es, es un ente; pero ¿tiene Dios que ser? ${ }^{59}$

Consideramos, entonces, que es legítimo el señalamiento de Marion sobre esta decisión en torno a Dios que lo reduce, como la onto-teología, a la condición de ente, anclando por demás el nuevo comienzo a un lastre metafísico, puesto que conserva el núcleo en el que gravita la estructura onto-teológica. El habitar del hombre en la tierra acontece, según Heidegger, en el Entre de Cielo y Tierra, en el que se co-pertenecen los divinos y los mortales. Medir este Entre es propiamente el poetizar, y esta medida es tomada por el poeta en relación con el Cielo y los divinos. $\mathrm{Al}$ menos esto querrá decir que lo sagrado, lo divino, los dioses y Dios le conciernen esencialmente al hombre, que en ello se juega su esencia. En consecuencia, podemos interpretar que la esencia del hombre, su decir y su hacer se tensan en este Entre, en la remisión a lo sagrado y a los dioses.

58 En este contexto, se hace difícil comprender el sentido de la afirmación de Heidegger de que el aparecer de los dioses no es una consecuencia del acontecimiento del lenguaje, sino que se da simultáneamente con él (Cfr. M. HeidegGer, "Hölderlin y la esencia...", 45). Si Dios es Dios dentro de la constelación del ser, ¿̨no es acaso más originario el acople de la constelación de tiempo-espacio-lenguaje que Dios mismo?

59 J. L. Marion, Dios sin el ser, 76. 
¿No implica esto que la esencia del hombre, en correspondencia con la esencia del poetizar como medida de la dimensión de la Cuaternidad, sigue dependiendo de un referente metafísico y onto-teológico: los entes divinos?

Contra la concepción entitativa de Dios, Marion afirma:

De Dios, admitamos claramente que no podemos pensarlo más que bajo la figura de lo impensable, pero de un impensable que rebasa tanto lo que no podemos pensar como lo que podemos pensar; pues lo que no puedo pensar concierne todavía a mi pensamiento y, por ello, sigue resultándome pensable. Lo impensable, por el contrario, tomado como tal, depende de Dios mismo y lo caracteriza como el aura de su advenimiento, la gloria de su insistencia, el estallido de su retiro. Lo impensable determina a Dios con el sello de su definitiva indeterminación para todo pensamiento creado y finito. Lo impensable encubre la separación, hendidura para siempre abierta, entre Dios y el ídolo, o mejor: entre Dios y la pretensión de toda idolatría posible $^{60}$.

Según Marion, Dios (tachando ahora mismo y en adelante esta palabra, dado que ningún conocimiento puede captarlo y porque se trata de una palabra que no define) debe ser pensado como lo impensable mismo y solo conviene llamarlo amor. Pero, ¿por qué el amor es un nombre o concepto icónico conveniente para indicar hacia la distancia de lo impensable que, por exceso, satura nuestro pensamiento?

Lo propio del amor es darse sin fundamento y sin condiciones que le antecedan. Como puro don, no requiere que el receptor lo reciba: solo se da. El amor como don no precisa, entonces, que se le prepare una morada para ser acogido; es lo incontenible que ningún dique puede detener; es lo que trastrueca las categorías, las estructuras y los a priori del pensamiento. "Si [...] Dios no es porque Él no tiene que ser, sino que ama, entonces, por definición, ninguna condición puede ya restringir su iniciativa, su amplitud y su éxtasis" ${ }^{61}$. El advenimiento del amor no depende de ninguna acción efectuada por el hombre, ni siquiera de su aceptación. "De este modo, incluso la inevitable impotencia del hombre

60 J. L. Marion, Dios sin el ser, 78.

61 J. L. Marion, Dios sin el ser, 79. 
para corresponder al destino que le impone gratuitamente el amor no basta para descalificar ni su iniciativa ni su cumplimiento"62.

El amor impide toda constitución idolátrica, porque ninguna mirada, ningún concepto puede fijarlo. El amor, como don excesivo, da que pensar, transgrediendo insistentemente los límites del pensamiento. Dios se da a pensar como amor, como don, como pensamiento del don y don para el pensamiento. ¿Qué pensamiento puede recibir el don? $\mathrm{Ha}$ de ser un pensamiento amante, porque "[el] amor, en su realidad íntima, solo puede ser conocido por el amor” (Hans Urs von Balthasar). Por supuesto, tal conocimiento no podrá ser un aprehender sino más bien un recibir en el éxtasis y el abandono de sí mismo: el amor (agápe) "excede todo conocimiento" (Efesios 3, 19). "Pero un don, que se da para siempre, solo puede pensarse mediante un pensamiento que se da al don que está por pensar. Solo un pensamiento que se da puede donarse a un don para el pensamiento" ${ }^{63}$.

\section{CONCLUSIÓN}

Para Marion, el pensamiento de Heidegger del Es gibt ("Se da"-"Ello que da”) es un pensamiento de la coincidencia entre el don y el Ser/ente: el don se piensa como la apropiación (Ereignis) entre tiempo y ser, entre ente y ser, y, por tanto, como la Cuaternidad. No hay distancia, según Marion, entre lo Ereignis y la Cuaternidad: "Don como apropiación, sin ninguna distancia" ${ }^{4}$. Sin embargo, es posible entender el don de otro modo, esto es, desde la donación en su reenvío al donador: "Entre el don dado y el donador donante, la donación no abre la (cuatri)-dimensión de la apropiación, sino que preserva la distancia" ${ }^{65}$. En la donación así entendida lo dado por el donador es reenviado a él mismo, en juego constante de envío y reenvío, propiciado por la distancia y en lo cual se guarda la distancia como tal: "La distancia abre la intangible separación por la cual circulan los dos términos que realizan en sentido inverso la donación" ${ }^{\prime 6}$. La distancia une y separa concertadamente: separa solo en la medida en que une. La distancia implica una separación irreductible:

\footnotetext{
62 J. L. Marion, Dios sin el ser, 79.

63 J. L. MARion, Dios sin el ser, 81.

64 J. L. Marion, Dios sin el ser, 150.

65 J. L. Marion, Dios sin el ser, 150.

66 J. L. Marion, Dios sin el ser, 150.
} 
una separación que desapropia. El término del donador en la distancia permanece siempre "enigmático", impensable.

Así, Marion contrapone dos modelos de don. Uno que él le atribuye a Heidegger, en el que el don como acontecimiento apropiador (Ereignis) coincide, sin separación ni distancia, con la Cuaternidad/mundo. El Es gibt (Il y a, en francés) indica la donación como el puro dar o acontecer, el gratuito hay mundo, que no remite a un donador. El otro modelo de don señala, a su vez, otro modo de la donación que conlleva la separación insuperable entre el Ser/ente, como lo dado, y la instancia impensable desde la que esta donación se ejerce. En la distancia como unión y separación, el agápe, que "[...] ni se conoce ni es sino que (se) $\mathrm{da}{ }^{\prime 67}$, es lo que abre la donación en cuanto que envío y reenvío: recorrido de distancia en que esta permanece como tal.

En el seno del agapé [sic], siguiendo su flujo como se sigue una corriente demasiado fuerte como para remontarla, una corriente demasiado profunda como para poder conocer su fuente y su valle, todo sigue la donación y, por la estela trazada en el agua, pero sin poder asir nada, todo indica el sentido de la distancia ${ }^{68}$.

En este punto, las divergencias interpretativas entre Marion y Corona son decisivas. Para Marion, todo aquí se juega en la disyuntiva entre apropiación (Ereignis) y distancia (agápe). Según esto, la apropiación de lo Ereignis no implica separación o distancia alguna entre el Ello y lo que da (entre el Es y el gibt-lo cual se indicaría con mayor precisión traduciendo Se da-). Ereignis sería entonces propiamente el darse de mundo, el acontecimiento-apropiación (más que apropiador, que todavía parecería indicar una instancia que apropia) de ser y entes, de espaciotiempo-lenguaje. Es claro que lo dado, el mundo, no remite según este paradigma a un donador. Recordemos que Néstor Corona, por su parte, afirma:

[...] Ereignis nombra el acontecimiento del dar -ya él más allá del ser-sentido- como siguiéndose de un Donador que así nombrado, sin embargo, en lo suyo más íntimo no es alcanzado por tal nombre. Lo que dona, dicho precisamente, está más allá, como tal, de $s u-\sin$ embargo-donar: ese el que, lo que, se sustrae a toda nominación (es

67 J. L. Marion, Dios sin el ser, 152.

68 J. L. Marion, Dios sin el ser, 152. 
el Ello de la expresión "Es [Ello] gibt"); su nombre más propio no es siquiera Donador ${ }^{69}$.

Corona traduce de este modo este otro pasaje crucial de Tiempo y ser:

[...] [I]ntentamos avanzar la mirada (vorzublicken) hacia el Ello que da ser y tiempo. Al avanzar así la mirada nos volvemos previsores (vor-sichtig) en un sentido nuevo. Intentamos traer a la vista (in die Sicht zu bringen) el Ello y su dar y escribimos el "Ello" con mayúscula ${ }^{70}$.

En la versión de Francisco Soler y Jorge Acevedo del mismo ensayo Tiempo y ser, leemos así este fragmento:

El camino apropiado [...] es que dilucidemos lo que es dado en el "Se da", lo que significa "Ser", que -Se da; qué significa "tiempo", que -Se da. Correspondientemente, nosotros intentamos mirar previamente al Se, que Ser y tiempo -da. Con tal mirar previo, nosotros nos volvemos, aún en otro sentido, pre-visores. Intentamos traer ante la vista al Se y su dar y escribimos al "Se" con mayúscula ${ }^{71}$.

En Tiempo y ser encontramos también la siguiente afirmación:

Pensar propiamente lo Ser requiere abandonar al ser como el fundamento de lo ente a favor del dar, esto es, del Se da, que se juega escondidamente en el desocultar. Ser pertenece en cuanto don de este Se da, al dar. Ser, en cuanto don, no está separado del dar ${ }^{72}$.

Así entonces, las dos interpretaciones que se han trazado a partir de Corona y de Marion tienen implicaciones divergentes: para Corona, el pensamiento de lo Ereignis implica pensar el Ello que apropia en sí ser y entes, tiempo-espacio-lenguaje, pero que se distingue de lo que dona y apropia. Es lo dador que dona, propiamente impensable, inefable, incognoscible, porque es lo que dona la posibilidad misma del pensamiento, el lenguaje, el conocimiento. Ereignis es un nombre que no nombra y que acaba indicando al silencio más originario. Corona encuentra, como veíamos, una posibilidad de pensar, desde Heidegger, a Dios por fuera de la Cuaternidad, en un más allá del ser. Dios sería asimismo un nombre que no nombra, sino que señala a Aquello que es

69 N. Corona, "La cuestión de Dios...", 269.

70 M. Heidegger, citado y traducido en N. Corona, "La cuestión de Dios...", 269.

71 M. Heidegger, "Tiempo y ser (Zeit und Sein)", en Filosofía, ciencia y técnica (Editorial Universitaria, Santiago de Chile 1997) 278.

72 M. Heidegger, “Tiempo y ser...”, 279. 
cantado y alabado por el poeta y el hombre religioso. Las dos vías: la del pensamiento, por un lado, y la de la poesía y la religión, por el otro, indicarían de modo distinto hacia lo que excede todo decir y todo pensar. El pensador lo nombra, callándolo, Ereignis. El poeta y el hombre religioso se entregan a ello con su vida. El canto del poeta y la alabanza del místico son respuesta al envío desde lo impensable. Para Marion, lo Ereignis como apropiación excluye toda distancia respecto a lo donado. El don es la apropiación misma como acontecer de mundo, sin distancia ni excedencia. Dice Marion, refiriéndose a Heidegger: "El dar (que se apodera del donador, del es/ça/eso) da sin donador de igual manera que la Cuaternidad no admite transgresión por fuera del Ser/ente"73. Como hemos visto, también Dios es situado, según Marion, bajo la constelación del ser, como un ente más en el juego de la dimensión cuaterna. Para Marion, no hay trascendencia -es decir, distancia- en el pensamiento del ser. Habría en el pensamiento de Heidegger, en definitiva, una equivalencia entre la donación y el ser, y la donación será pensada como puro dar, como acontecimiento-apropiación, como apertura de la Cuaternidad que no admite ir más allá del propio juego Ser/ente en que esta consiste. Además, mientras que Corona comprende el destino del poeta íntimamente relacionado con la vocación del hombre religioso, para Marion ambos atienden a llamadas diversas. El poeta está inmerso en el círculo hermenéutico de la escucha y el decir desde la escucha, que no escapa a la Cuaternidad. El circuito del don es aquí el mismo círculo hermenéutico. Entre el Decir originario (Sage) y el habla humana (Sprache) no se abre una real distancia, puesto que el envío y el reenvío del Decir al habla y del habla al Decir acontecen en el seno de la Cuaternidad. Podemos interpretar que, para Marion, la gracia del amor, lo propiamente impensable, es otra que la gracia que, como veíamos en De un diálogo acerca del habla, arrastra al silencio del Decir originante. En Heidegger, la gracia (cháris) es la inclinación benevolente que poetiza, que propicia la poiesis como surgir, desde el ocultamiento, del juego entre el ser y los entes -la Duplicidad-. Esta gracia se inclina benevolente, no desde la radical distancia de lo verdaderamente impensable, sino desde el mismo juego Ser/entes. El silencio del ser, la brisa que arrastra desde y hacia la dimensión del acontecimiento-apropiación (Ereignis), de donde provienen las palabras y donde son reconducidas en su des-

73 J. L. MARIOn, Dios sin el ser, 149. 
pliegue esencial, no coincide, para Marion, con lo impensable mismo. Se trata, por lo tanto, de otra idolatría que, en cuanto tal, no permite remontar la mirada a la profundidad infinita sino que la retiene dentro los cercos de la dimensión cuaterna. En cambio, la vocación del hombre religioso es convocación a otro silencio:

Todo silencio que permanezca inscrito en la banalidad, en la metafísica y también en el Ser/ente o incluso en una teología que olvida los nombres divinos, no ofrece más que ídolos mudos. No basta con callarse para escapar a la idolatría $[\ldots]^{74}$.

La vocación se resuelve asimismo en la forma de la alabanza a partir de los nombres de Dios. Relacionados íntimamente con la noción de icono en Marion, los nombres de Dios, como nos enseña Dionisio Areopagita, encarnan e indican la inadecuación esencial, esto es, la imposibilidad de nombrar lo impensable mismo; manifiestan la distancia que une en cuanto que separa; y hacen posible la alabanza, en la que se revela la imposibilidad del pensamiento.

La alabanza -que también articula un discurso- y el silencio son las únicas respuestas posibles a la interpelación del amor, de lo impensable mismo, desde la distancia. Por una parte, la alabanza se despliega entonces en el espacio de una imparticipable comunión de amor, como relación en la distancia del amor extático. Por otra parte, el silencio que aquí se nombra no es cualquier silencio, porque, como antes se dijo, no todo silencio corresponde a la dignidad del envío impensable:

El silencio que conviene al Dios que se revela como agápe en Cristo consiste en callarse por y para el agapé [sic]; consiste en concebir que si Dios da, entonces nombrar a Dios impone recibir el don y-puesto que el don solo adviene en la distancia- devolverlo. Devolver el don, jugar en redundancia la donación impensable, es algo que no se dice, sino que se hace. Solo entonces puede renacer el discurso, pero ya como un goce, un júbilo, una alabanza ${ }^{75}$.

Nos queda por meditar sobre el hombre ya no como Dasein, y ni siquiera como determinado en su esencia por el habitar poético en la Cuaternidad del mundo, sino como el interpelado ${ }^{76}$ que se recibe en el

74 J. L. Marion, Dios sin el ser, 153.

75 J. L. Marion, Dios sin el ser, 153.

76 Cfr. J. L. Marion, "El sujeto en última instancia", en Revista de Filosofia, 6/10 (1993, 3a época) 439-458. 
316 | Santiago Andrés Duque

envío desde lo anónimo del misterio que se le revela como amor. El interpelado corresponderá a la interpelación del amor con el lenguaje del hymnein-alabanza- y con el silencio de la entrega de su propia vida. Es decir, responderá siempre diciendo gracias. 